\title{
P02.178. Skin conductance at 24 Source (Yuan) acupoints in 8637 patients: influence of age, gender and time of day
}

\author{
S Chamberlin ${ }^{1 *}$, A Colbert $^{1}$, A Larsen ${ }^{2}$ \\ From International Research Congress on Integrative Medicine and Health 2012 \\ Portland, Oregon, USA. 15-18 May 2012
}

\section{Purpose}

The clinical practice of recording skin conductance (SC) at acupuncture points (acupoints), as a diagnostic and/ or therapeutic monitoring aid may have scientific merit. However, influences of age, gender and time of day on these recordings are unknown and it is unclear whether SC at acupoints differs from SC levels in general (as reported in psychophysiology research). This research will investigate these influences.

\section{Methods}

This analysis summarizes SC data obtained with the AcuGraph 3 Digital Meridian Imaging System between June 2005 and March 31, 2010. An initial dataset of 117,725 SC examinations was scrubbed to include only the first SC examination on individual patients and exclude potentially faulty data. The final dataset consists of SC recordings at the 24. Source (Yuan) acupoints in 8637 patients, collected by 311 practitioners. Twelve left/right average conductance measures and an overall average of the 24 acupoints were assessed. Statistical analyses included two sample $t$ tests, three way analyses of variance and linear regression.

\section{Results}

Results indicate that mean SC at acupoints, similar to $\mathrm{SC}$ in general, is higher in males, higher in afternoons and declines with age. Not previously reported, the rate of SC decline with age differs at different acupoints between males and females.

${ }^{1}$ National College of Natural Medicine, Helfgott Research Institute, Portland, USA

Full list of author information is available at the end of the article

\section{Conclusion}

These findings have substantial implications for acupuncture research and practice. Patterns derived from measures such as these should be investigated as potential early detectors of disease and predictors of treatment responsiveness.

\section{Author details \\ ${ }^{1}$ National College of Natural Medicine, Helfgott Research Institute, Portland, USA. ${ }^{2}$ Meridia Technologies, Inc., Meridian, USA.}

Published: 12 June 2012

doi:10.1186/1472-6882-12-S1-P234

Cite this article as: Chamberlin et al:: P02.178. Skin conductance at 24 Source (Yuan) acupoints in 8637 patients: influence of age, gender and time of day. BMC Complementary and Alternative Medicine 201212 (Suppl 1):P234.

Submit your next manuscript to BioMed Central and take full advantage of:

- Convenient online submission

- Thorough peer review

- No space constraints or color figure charges

- Immediate publication on acceptance

- Inclusion in PubMed, CAS, Scopus and Google Scholar

- Research which is freely available for redistribution

\section{Biomed Central}

